\title{
Penetrating Facial Injury by a Tree Branch: a Case Report
}

\author{
${ }^{1}$ Marthinson A. Tombeng, ${ }^{1}$ Eko Prasetyo, ${ }^{2}$ Nico A. Lumintang, ${ }^{1}$ Maximillian Ch. Oley
}

\author{
${ }^{1}$ Division of Neurosurgery, Department of Surgery, Faculty of Medicine of Sam Ratulangi \\ University/Prof. Dr. R. D. Kandou General Hospital, Manado, Indonesia \\ ${ }^{2}$ Division of Head and Neck Surgery, Department of Surgery, Faculty of Medicine of Sam \\ Ratulangi University/Prof. Dr. R. D. Kandou General Hospital, Manado, Indonesia \\ Email: tombengma@gmail.com
}

\begin{abstract}
Abstrak: Cedera tembus wajah dapat berbahaya karena adanya struktur-struktur penting pada wajah yang membutuhkan penanganan dengan cepat dan tepat. Benda asing organik dapat menyebabkan risiko tinggi infeksi luka. Kami memresentasikan suatu kasus yang jarang ditemukan yaitu seorang laki-laki berusia 19 tahun dengan luka tembus wajah oleh patahan cabang pohon akibat kecelakaan sepeda motor. Panjang cabang pohon $25 \mathrm{~cm}$ dengan diameter sekitar $4 \mathrm{~cm}$, menembus melalui sisi depan kanan wajah, tepat di samping hidung, dan menjorok keluar melalui sudut kanan mandibula. Evaluasi dan penatalaksanaan cedera tembus wajah dilakukan mengikuti protokol ATLS. Tujuan penatalaksanaan cedera tembus wajah ialah mengeluarkan benda asing dengan trauma minimal pada struktur berdekatan dan mempertahankan fungsi dan penampilan yang normal. Pasien ini menjalani operasi darurat untuk pengangkatan benda asing dan eksplorasi luka dengan anestesi umum. Evaluasi pasca operasi tidak mendapatkan adanya perdarahan maupun tanda-tanda infeksi. Defisit neurologik pada wajah kanan diterapi secara konservatif dengan terapi fisik dan pulih sepenuhnya satu tahun pasca kecelakaan.
\end{abstract}

Kata kunci: luka tembus, trauma wajah, cabang pohon

\begin{abstract}
Penetrating facial injury can be dangerous because of the presence of important structures in the face which requires immediate and proper management. Organic foreign bodies may cause a high risk of wound infection. We present a case of a 19-year-old male with an unusual penetrating facial injury by a broken tree branch due to a motorcycle accident. The length of the tree branch was $25 \mathrm{~cm}$ with a diameter of approximately $4 \mathrm{~cm}$, penetrating through the right anterior side of his face, just lateral to the nose, and protruding through the right angle of the mandible. The evaluation and management of the penetrating facial injury were performed in accordance with the ATLS protocol. The aim of the penetrating facial injuries management is to remove foreign body with minimal trauma to adjacent structures and to maintain the normal function and appearance. The patient underwent emergency surgery for removal of the foreign body and wound exploration under general anesthesia. In postoperative evaluation, there was not any bleeding or signs of infection. The neurological deficit in the right face was managed conservatively with physical therapy and was fully recovered in 1 year after the accident.
\end{abstract}

Keywords: penetrating wound, facial trauma, tree branch

A penetrating injury is defined as an injury that occurs as a result of an object that violates cutaneous or mucosal barriers and enters the body. Penetrating wounds are classified as high velocity and low velocity, or projectile and non-projectile wounds. ${ }^{1,2}$ Projectile penetrating facial injuries most often result from gunshot injuries meanwhile non-projectile penetrating facial injuries most often result from injuries by 
sharp items such as knives, glasses, stones, screw-drivers, or tree branches. ${ }^{2-4}$ Foreign bodies are often found in penetrating facial wound but rarely reported in the literature. ${ }^{5}$

Penetrating facial injuries require proper and careful treatment because of the potential injuries that can occur during removal of the retained foreign bodies. Early wound exploration and proper wound debridement with adequate antibiotic administration are the major factors in preventing morbidity and mortality. ${ }^{3}$

We present a case of an unusual penetrating facial injury caused by a broken tree branch.

\section{Case Report}

A 19-year-old male motorcyclist was brought to the Surgery Department of Prof. Dr. R. D. Kandou General Hospital, Manado with a history of motorcycle accident one hour prior to admission. The motorcycle crashed into a tree which caused accidental penetration of the patient's right face by a tree branch (Fig. 1). The patient sustained a penetrating facial injury by a piece of tree branch passing through the right anterior side of his face, just lateral to the nose, and protruding through the right angle of mandible. Upon admission, the patient complained of pain over the injury site with a retained foreign body in the patient's right face. The patient was conscious, coherent, and not in respiratory distress. $\mathrm{He}$ was hemodynamically stable. There was no history of loss of consciousness.

On examination, the length of the piece of tree branch was around $25 \mathrm{~cm}$ with a diameter of approximately $4 \mathrm{~cm}$ ). There was mild bleeding from the wound. Oral cavity and oropharynx appeared normal. Plain AP-lateral skull X-ray revealed the presence of a foreign body in the right facial tissues. No bone fracture was observed (Fig. 2).

The management of the patient was done first with primary survey which began with a rapid assessment of the airway, breathing, and circulation according to the guidelines of the advanced trauma life support (ATLS). ${ }^{6}$ The airway of this patient was adequate; however, the patient was given oxygen 2 Liters/min. After the airway was secured, the following steps done were evaluation of breathing and circulation. Since the patient was stabilized, secondary survey was conducted, which included a complete history and a thorough physical examination.

\section{Surgical procedure}

The patient underwent emergency operation for the removal of the foreign body and wound exploration under general anesthesia (Fig. 3A-C). The patient was put in supine position with his head slightly turned to the left. Incisions were done around the penetrating wound's entry and exit points. After adequate exposure, the tree branch was carefully extracted back along the path of insertion (Fig. 4). Wound exploration and debridement were done to remove any debris. Hemostasis was achieved and the area was cleaned with betadine, hydrogen peroxide, and saline wash. There was no injury of great vessels. There was partial tear of masseter muscle, which was subsequently repaired using Safil (polyglycolic acid) resorbable sutures. Wound was then closed in layers after securing the penrose drain. Skin closure was performed using non-resorbable monofilament interrupted sutures. The patient was given adequate antimicrobial and tetanus prophylaxis to reduce the chances of wound infection.

Post-operative evaluation found no bleeding or signs of infection (Fig. 5A). There was moderate swelling of the site of injury on the 1st post-operative day, which was gradually reduced in size on the $3 \mathrm{rd}$ post-operative day. The patient was discharged on the 7th post-operative day (Fig. 5B). There was a focal neurological deficit on the right side of the face signified by the inability of the patient to elevate his right upper lip, suggesting an injury of the buccal branch of the right facial nerve but still had normal symmetry and tone at rest, as well as normal eyes and mouth function (Grade II mild dysfunction in the House- 
Brackmann facial nerve grading system). This incomplete facial weakness was managed conservatively with physical therapy. He was followed-up 2 weeks after operation with good recovery and no major complaints (Fig. 5C). Moreover, the patient had full recovery and was able to elevate his right upper lip at follow-up one year after operation (Fig. 5D).

\section{Discussion}

Penetrating trauma to the face may cause significant morbidity and mortality. Although much attention has been focused on treatment algorithms for patients with penetrating trauma to the neck, chest, and abdomen, there are less written reports and literature about penetrating injuries to the face. $^{5,7}$

Face is important to human function and appearance. Facial trauma can be very dangerous because it can impair several important functions of human life including respiration, mastication, deglutition, vision, smell, and the expression of the focal of both verbal and non-verbal communication, so special attention should be given to facial trauma patients. ${ }^{8,9}$ The maxillofacial region also demands the highest attention because of increased cosmetic needs. ${ }^{4}$ According to Motamedi ${ }^{10}$ there are several things that have been proven to influence the final outcome and aesthetic result, such as the general condition of the patient, timing and sequence of the operations, extent of damage, and proper application of appropriate surgical hardware. In this case, there were no impairments of the important functions due to facial trauma and overall, the final outcome was good.

Penetrating facial injury may cause a serious problem to the airway and breathing. Swelling or excessive bleeding that can occur later, may cause airway obstruction. Evaluation of penetrating facial injury should follow protocols of ATLS, with primary importance to the assessment of airway, breathing, and circulation. ${ }^{6}$ In this case, the airway of the patient was adequate, but the part of the tree branch that protruded superior to the mouth limited the mouth opening itself, hence making it more difficult for intubation to be performed before the removal operation of the tree branch.

Organic foreign bodies, like the tree branch, are contaminated and can cause serious infection if not removed promptly and treated with adequate antibiotic coverage, and thus they cannot be left in situ. ${ }^{11}$ In this case, the patient with penetrating facial injury by a piece of tree branch required emergency operation to remove the foreign body and it was performed with primary treatment. Ueeck ${ }^{1}$ defined primary treatment as initial treatment of a wound within 48 hours with the intent to definitively manage all aspects of the injury. The goal of primary treatment is to repair the wound. Both hard and soft tissue, and all wounds are primarily closed. ${ }^{1}$ Wound debridement and irrigation were done to prevent retention of any foreign objects in the trauma site. Agrawal et $\mathrm{al}^{11}$ stated that in the case of organic foreign bodies, early exploration and removal reduces the chances of wound infection, resulting in a favorable outcome. Blind removal of objects may cause lifethreatening hemorrhage because sometimes injured major vessels might be tamponaded by foreign bodies, therefore foreign bodies removal should always be explored in a proper setup. ${ }^{11}$ In this case there were no physical signs of major vessel injury such as active bleeding, expanding hematoma, bruit, pulse deficit, etc. The surgical aim is to remove any foreign body with minimal trauma to adjacent structures. Moreover, the aim of management of isolated facial injuries is the maintenance of normal function and appearance. ${ }^{12}$

Parenteral antibiotics and tetanus prophylaxis were given to reduce the risk of wound infection. A thorough patient's history and physical examination, radiologic evaluation, early decision-making, proper treatment, and frequent follow-up resulted in an optimal treatment outcome.

According to Gordin et al, ${ }^{13}$ facial paralysis can result from a wide range of causes, including trauma to the face, such 
as penetrating facial injury. Electroneurography and electromyography are the mainstays of facial nerve testing, ${ }^{13}$ but were not performed in this case because of the unavailability of the required facilities. The patient was instead physically reexamined after the removal operation of the foreign body and was found to have a focal neurological deficit on the right side of the face, signified by the inability of the patient to elevate his right upper lip, suggesting an injury to the buccal branch of the right facial nerve; however, because of the position of the tree branch prior to its removal, it was difficult to determine with certainty whether the onset of this paresis happened before or after the operation. The House-Brackmann facial nerve grading system is the most commonly used scale for evaluating the degree of facial weakness based on the facial clinical presentation. ${ }^{13,14}$ In this patient, the focal neurological deficit was classified as grade II which was mild dysfunction.

In this case, the facial paralysis was managed conservatively with physical therapy. Kumar et $\mathrm{al}^{15}$ recommended that all patients of facial nerve palsy should be given conservative management first, albeit, if there was no recovery at the end of three months then surgery might be considered. Turel et $\mathrm{al}^{16}$ in their study concluded that most patients of posttraumatic facial nerve injuries recovered with conservative treatment and time. Therefore, nerve injuries medial to the lateral canthus are typically not explored because nerve regeneration is usually adequate. $^{7}$

\section{Conclusion}

Penetrating trauma in the facial region by a tree branch is an uncommon, but potentially life-threatening condition, therefore, making the management more challenging, as there are several of important structures, such as blood vessels and nerves in a relatively small area. The contamination that may be present in the tree branch also presents the risk of infection, therefore, antibiotic treatment and tetanus prophylaxis were given to reduce the risk of infection.

The patient in this case underwent emergency surgery for removal of the foreign body and wound exploration under general anesthesia. Postoperative evaluation did not found any bleeding or signs of infection. The neurological deficit in the right face was managed conservatively with physical therapy and was fully recovered in one year after the accident.

\section{References}

1. Ueeck BA. Penetrating injuries to the face: delayed versus primary treatmentconsiderations for delayed treatment. J Oral Maxillofac Surg. 2007;65(6): 1209-14.

2. Offiah C, Hall E. Imaging assessment of penetrating injury of the neck and face. Insights Imaging. 2012;3:41931.

3. Mohan S, Varghese G, Kumar S, Subramanian DP. Penetrating facial injury by a wooden log. Natl J Maxillofac Surg. 2014;5:228-31.

4. Mohanavalli S, David JJ, Gnanam A. Rare foreign bodies in oro-facial regions. Indian J Dent Res. 2011;22(5):713-5

5. Santos TS, Melo AR, Moraes HHA, Avelar RL, Becker OE, Haas OL, et al. Impacted foreign bodies in the maxillofacial region - diagnosis and treatment. J Craniofac Surg. 2011; 22:1404-8.

6. Advanced Trauma Life Support Student Course Manual (10th ed). Chicago: American College of Surgeons, 2018; p. 7-10.

7. Stewart MG. Penetrating face and neck trauma. In: Bailey BJ, Johnson JT, Shawn D, et al, editors. Head \& Neck Surgery-Otolaryngology, vol 1. Newlands: Lippincott Williams \& Wilkins, 2006; p. 1017-26.

8. Kellman RM. Face. In: Mattox KL, Moore EE, Feliciano DV, editors. Trauma (7th ed). New York: The McGraw Hill Companies, 2013; p. 395-413.

9. Rankin M, Borah GL. Perceived functional impact of abnormal facial appearance. Plast Reconstr Surg. 2003;111(7): 2140-6.

10. Motamedi MHK. Primary treatment of 
penetrating injuries to the face. J Oral Maxillofac Surg. 2007;65:1215-8.

11. Agrawal R, Timilsina D, Reddy $\mathbf{N}$, Ganguly S, Tayal A. Penetrating foreign body neck: a case report. Kathmandu University Medical Journal. 2007;5(3):414-6.

12. Macken L. Facial trauma. In: Cameron $P$, Jelinek G, Kelly AM, Brown AFT, Little M, editors. Textbook of Adult Emergency Medicine (4th ed). New York: Elsevier Health Sciences, 2014; p. 98.

13. Gordin E, Lee TS, Ducic Y, Arnaoutakis D. Facial nerve trauma: evaluation and considerations in management.
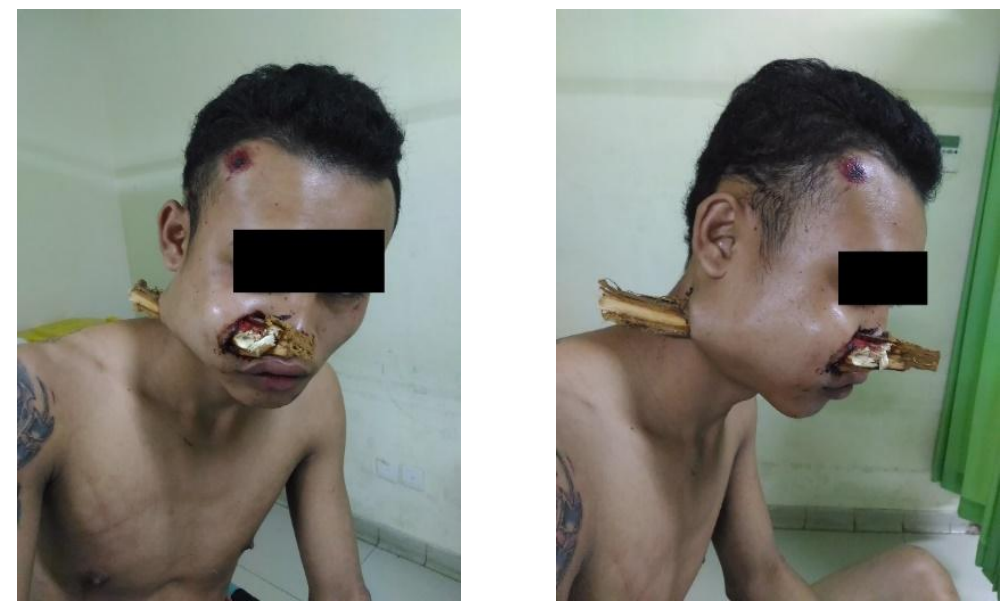

Figure 1. Preoperative anterior dan lateral views

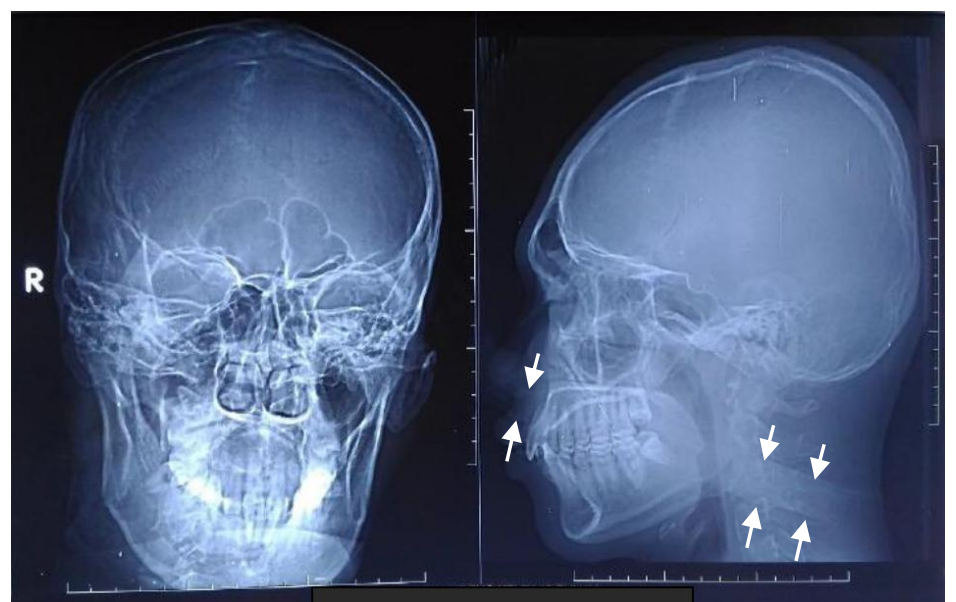

Figure 2. Skull X-ray revealed a foreign body (arrows) on the right facial area without any bone fracture struction. 2015;8:1-13. Neck Surg. 1985;93(2):46-7. (XXII)1:116-9. 2005;2(1):33-4.

Craniomaxillofacial Trauma Recon-

14. House JW, Brackmann DE. Facial nerve grading system. Otolaryngol Head

15. Kumar R, Bajaj J, Purohit D, Mittal R. Post-traumatic acute bilateral facial nerve palsy-a management dilemma. Romanian Neurosurgery. 2015; XXIX

16. Turel KE, Sharma NK, Verghese J, Desai S. Post traumatic facial paralysis treatment options and strategies. Indian

Journal of Neuro-trauma (IJNT). 


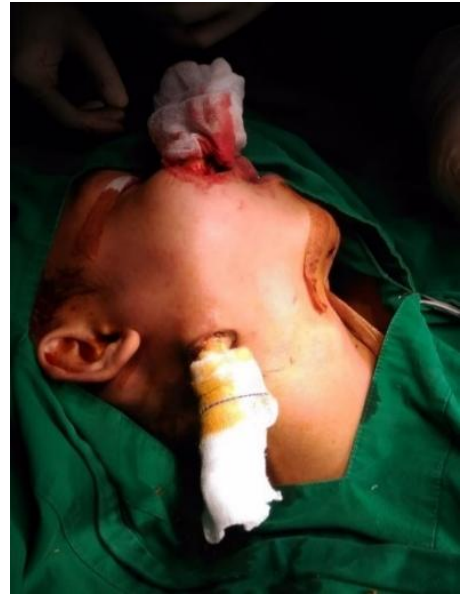

Figure 3A. Supine position with head slightly turned to the left

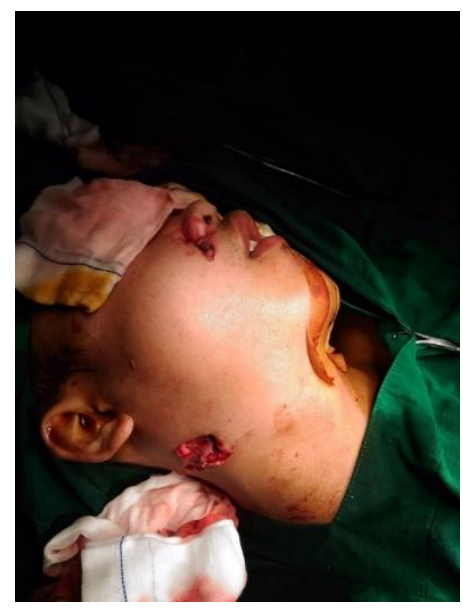

Figure 3C. After wound exploration and debridement

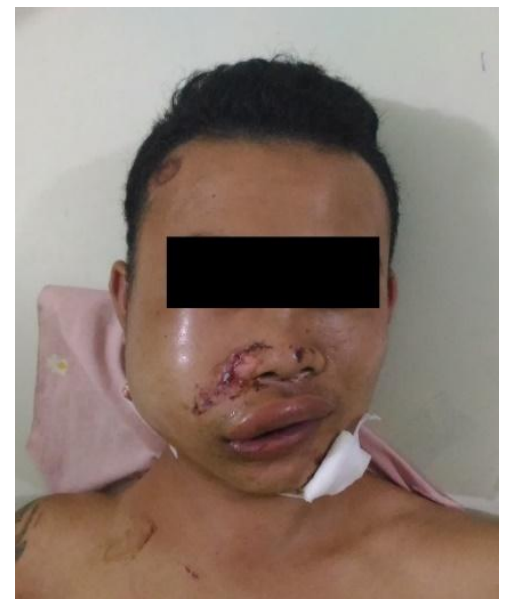

Figure 5A. Post-operative day 1

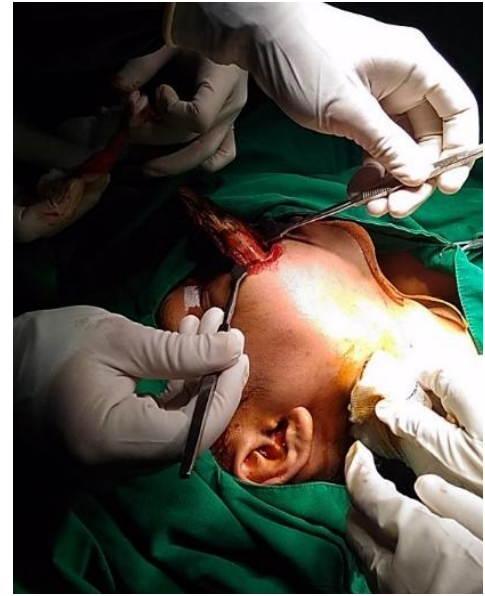

Figure 3B. Removal of the tree branch back along the path of insertion

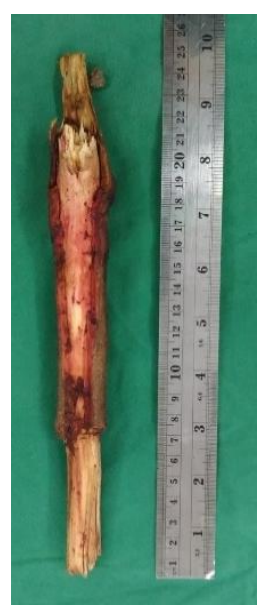

Figure 4. Piece of the tree branch after removal, (length 25 $\mathrm{cm}$, diameter approximately 4 $\mathrm{cm})$

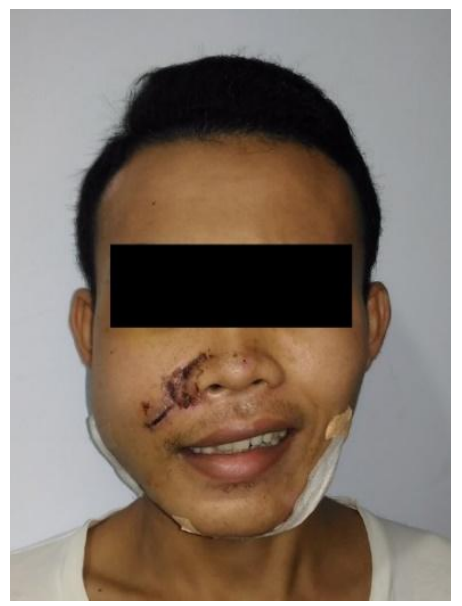

Figure 5B. Post-operative day 7 

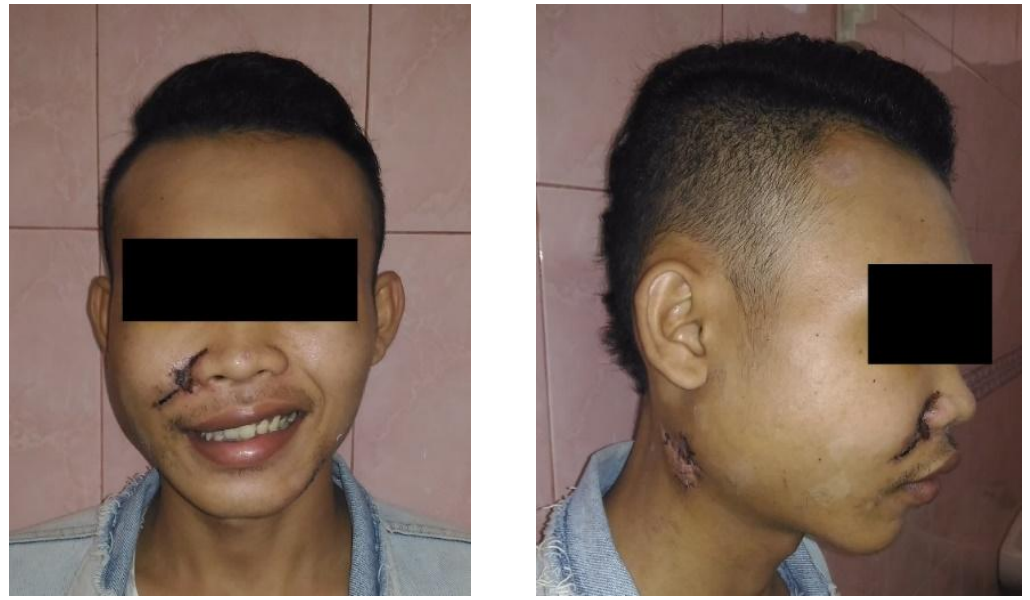

Figure 5C. Post-operative day 14, anterior and lateral views
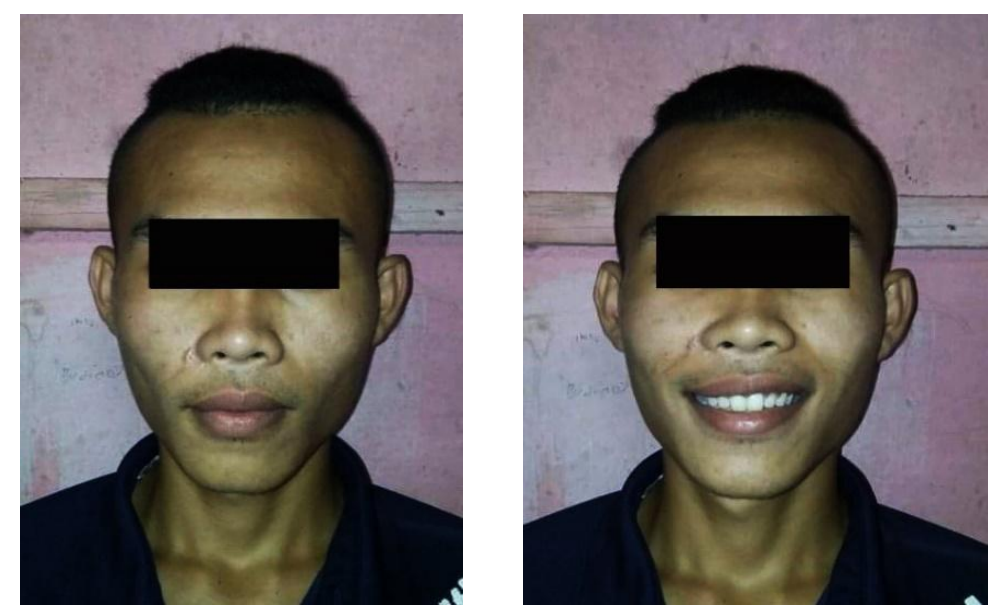

Figure 5D. Post-operative one year showed full recovery. 